\title{
Strategi pemeliharaan relasional dalam kegiatan public relations online badan publik di Indonesia
}

\author{
Syaiful Azhary \\ BKT Kebun Raya Purwodadi, Lembaga Ilmu Pengetahuan Indonesia, Pasuruan, Indonesia
}

\begin{abstract}
ABSTRAK
Praktik humas di negara demokratis harus menyajikan informasi yang akurat dan dalam bentuk komunikasi dua arah. Tujuan dari penelitian ini adalah untuk menganalisis implementasi strategi public relations online dalam website resmi yang dijalankan oleh lembaga-lembaga publik di Indonesia menggunakan analisis strategi pemeliharaan relasional. Penelitian ini menggunakan metode analisis strategi pemeliharaan relasional dari Grunig dan Huang, 1999, dengan pendekatan positivisme dan metode penelitian kuantitatif dan kualitatif. Dengan menggunakan analisis isi berupa fitur strategi pemeliharaan relasional pada website dan proporsional stratified random sampling berdasarkan hasil pemeringkatan penghargaan keterbukaan informasi badan publik di Indonesia tahun 2016. Hasil penelitian ini dapat digunakan sebagai bahan evaluasi, rekomendasi, dan bimbingan teknis oleh badan publik dalam membangun fitur yang mendukung transparansi dan akuntabilitas informasi kepada publik. Hasil penelitian menunjukkan bahwa humas badan publik di Indonesia lebih cenderung menggunakan platform media sosial untuk pemeliharaan relasional dengan publik daripada memanfaatkan fitur strategi pemeliharaan hubungan di website resmi mereka. Masih terdapat kesalahpahaman cara pandang humas badan publik di Indonesia dalam mendefinisikan aktivitas public relations online identik dengan pemanfaatan media sosial dalam kegiatan kehumasan. Selain itu, peraturan keterbukaan informasi publik belum cukup untuk memastikan transparansi dan akuntabilitas informasi dilihat dari penggunaan fitur pemeliharaan relasional. Dibutuhkan kerangka acuan, pengetahuan dan pengalaman di bidang kehumasan dalam meningkatkan pengelolaan website yang informatif dan dialogis serta mampu menjalin hubungan baik dengan publik untuk mewujudkan transparansi dan akuntabilitas informasi.
\end{abstract}

Kata-kata Kunci: Strategi; humas online; pemeliharaan relasional; badan publik; keterbukaan informasi publik

\section{Relational maintenance strategy in online public relations activities of Indonesian public agencies}

ABSTRACT

Public relations practices in democratic countries must provide accurate information and in the form of twoway communication. The purpose of this study is to analyze the implementation of online public relations strategies in official websites run by public institutions in Indonesia using an analysis of relational maintenance strategies. This study uses the method of relational maintenance strategy analysis from Grunig and Huang, 1999, with the positivist approach and both quantitative and qualitative research methods. The content analysis applied in the form of a relational maintenance strategy feature on the website and proportional stratified random sampling based on the ranking results of the award of information disclosure of public agencies in Indonesia in 2016. The results of this study applied as evaluation material, recommendations, and technical guidance by public agencies in building features that support information transparency and accountability to the public. The results show that public relations public agencies in Indonesia are more likely to use social media platforms for relational maintenance with the public than using the relationship maintenance strategy feature on their official website. There is still a misconception of public relations in Indonesia in defining online public relations activities synonymous with the use of social media in public relations activities. It indicates that the regulation of public information disclosure is not sufficient to ensure transparency and accountability of information from the perspective of maintaining relationships. A frame of reference, knowledge, and experience is needed in the field of public relations in improving the management of informative and dialogical websites and being able to establish good relations with the public to recognized transparency and accountability of information.

Keywords: Strategy; online PR; relational maintenance; public agencies; public information disclosure

Korespondensi: Syaiful Azhary, SST. Par., M. I.Kom. BKT Kebun Raya Purwodadi - LIPI. Jl. Raya Surabaya - Malang Km. 65 Purwodadi - Pasuruan 67163.Email: diasya_0303@yahoo.com 


\section{PENDAHULUAN}

Pelaksanaan peraturan keterbukaan informasi publik seharusnya telah membuat website badan publik di Indonesia telah menerapkan strategi pemeliharaan hubungan dalam aktivitas public relations online selama ini. Setiap kebijakan, rencana kerja, dan pencapaian kinerja kepada publik harus dapat dikomunikasikan oleh humas badan publik di Indonesia, baik melalui media tradisional, media konvensional, dan media baru sehingga masyarakat bisa mengetahui setiap informasi yang dihasilkan secara lengkap dan jelas. Hal ini sejalan dengan tuntutan peraturan keterbukaan informasi publik sebagaimana telah diatur dalam peraturan Undang-Undang Nomor 14 Tahun 2008 yang diikuti oleh Keputusan Menteri Negara Kepegawaian No. 20/2010 dan diikuti oleh Keputusan Menpan RB Nasional No. 83/2012 tentang Pedoman untuk Pemanfaatan Media Sosial Badan Publik. Dengan kata lain humas badan publik selalu dituntut untuk dapat meningkatkan kemampuannya dalam menghadapi tantangan dan perubahan lingkungan yang sangat cepat dan mampu menjadi jembatan untuk membangun suasana yang kondusif bersama masyarakat melalui proses komunikasi yang baik.

Petugas public relations harus memperluas pemahaman tentang teknologi baru dan aplikasinya untuk melihat isu-isu tentang hubungan relasi dan hubungan sosial dengan baik serta mengaplikasikan dalam keseharian mereka (Kent \& Suffer, 2014). Ditambahkan oleh Yang dan Taylor, komunikasi dalam media sosial bagi suatu institusi memiliki resiko yang cukup besar namun dibutuhkan transparansi informasi bagi khalayak banyak (Yang dan Taylor, 2015). Selain itu komunikasi dialogis memberikan peluang bagi paraktisi public relations yeng memanfaatkan teknologi digital dalam membangun relasi antara organisasi dengan masyarakat disekitarnya sebagai suatu kesatuan lingkungan sosial. Seperti yang telah diketahui bersama, internet tidak hanya mengubah dunia secara radikal tetapi juga dalam praktik public relations (Brown, Sikes, \& Willmott, 2013).

Saat ini, internet telah menjadi tidak hanya menjadi alat vital dalam praktik public relations tetapi juga sangat penting bagi kebanyakan orang (Petrovici, 2014). Kehadiran internet telah membuka pintu bagi praktisi public relations untuk dapat melakukan komunikasi dua arah antara perusahaan atau instansi kepada publiknya dalam konsep interactivity (Kelleher, 2007). Dalam Teori interaktivitas disampaikan bahwa interaktivitas adalah suatu proses pertukaran pesan (Voorveld et al., 2013).

Sebagai gatekeepers dalam pemeliharaan relasi yang menjembatani komunikasi 
organisasi dengan publik secara online, praktisi public relations berada dalam posisi yang diuntungkan untuk memantau dan memahami perubahan materi yang terjadi dalam ekologi jaringan digital selama dan setelah peristiwa disebarluaskan (Nahon \& Hemsley, 2013). Hal ini tak lepas dari prinsip interaktivitas sebagai salah satu ciri penting media baru, sebagaimana dikemukakan McQuail (2010: 144) yang memungkinkan masyarakat (users) mengirim pesan, baik itu berupa pengaduan atau saran kepada pemerintah. Seorang public relations tidak hanya harus mampu memberi informasi tetapi juga bisa menjadi wadah yang bisa menggali informasi dari segenap publik (Ishak, 2011).

Berkaitan dengan itu, pengelola website harus memiliki pengetahuan tentang kegunaan, desain interface, desain website, dan memberikan perhatian lebih dalam hal interaktivitas dengan publik organisasinya (Holzschlag, 2001). Semakin sering terjadi pertukaran pesan timbal balik maka semakin kuat terbentuk persepsi terjadinya interaktivitas (Voorveld et al., 2013). Dari beberapa literatur terlihat adanya keterkaitan antara teori interaktivitas dalam setiap komunikasi manusia (Boczkowski \& Mitchelstein, 2012). Namun disisi lain, sampai saat ini masih sangat sedikit website yang difasilitasi dengan dialog publik atau konsultasi secara online. Justru sebagian besar inisiatif e-government masih melihat orang dari perspektif pasif (Pratchett, 1999; Pina, dkk., 2007a \& 2007b; \& Torres, dkk., 2006).

Hingga saat ini public relations pemerintah masih dominan menggunakan strategi komunikasi satu arah dan enggan menerima kritik dari media massa serta sebagian besar kerjanya adalah mengelola event pemerintah (Sunarto, 2011) menyatakan bahwa. Hal tersebut menunjukkan bahwa praktisi public relations sangat diperlukan oleh pemerintah, terutama bagi negara yang demokratis karena sejatinya tujuan demokrasi sendiri secara erat kaitannya dengan tujuan humas. Hal ini menjadi tantangan bagi pemerintah di semua negara untuk berbenah diri dengan berupaya melibatkan warganya dalam kegiatan demokrasi (Sala, 2003).

Dalam komunikasi dialogis, public relations harus memberikan perhatian kepada nilai-nilai dan kepercayaan orang lain, merasa berkewajiban untuk mengambil risiko keterlibatan dalam dialog terbuka untuk memungkinkan penemuan, merangkul penciptaan realitas bersama, dan berdedikasi pada kebenaran dan saling pengertian bagi para peserta untuk saling berkomitmen satu sama lain (Taylor \& Kent, 2014). Penelitian lebih lanjut dari media online perlu mempertimbangkan seberapa banyak publik yang bergerak yang 
berfungsi sebagai anggota komunitas daring yang paling baik terlibat melalui keterhubungan emosional serta rasional dalam penyampaian pesan strategis (Duhé, 2015). Ditambahkan oleh Castells yang menyatakan bahwa kekuatan jaringan digital pribadi ini dapat menjembatani hubungan, dan kemampuan kita untuk memanfaatkannya, jadi tidak ada alasan bagi pemerintah untuk takut terhadap internet (Castells, 2015).

Negara Indonesia yang menganut demokrasi Pancasila menempatkan kebersamaan dan keterbukaan menjadi bagian yang penting. Oleh karena itu dalam Permenpan Nomor 30 Tahun 2011 menyatakan bahwa komunikasi yang dikelola humas pemerintah pusat dan daerah yang berjalan dua arah adalah suatu program yang realistis dan logis untuk bisa dilaksanakan. Dalam era informasi, praktik humas pemerintah telah bergeser dari komunikasi interpersonal (satu arah) ke arah the new electro-personal (komunikasi interaktif) sehingga pemimpin pemerintahan serta petugas humas mau tidak mau harus mengubah strategi dan taktik komunikasi mereka sesuai dengan era sekarang (Caywood, 1997).

Perkembangan teknologi informasi dan komunikasi dan UU KIP harusnya dapat menjadi kekuatan dan pegangan bagi humas badan publik dalam mengoptimalkan fungsinya dan tidak lagi sebatas alat propaganda atau penyedia informasi. Humas badan publik idealnya telah menjadi agen demokrasi dan menjalankan model komunikasi two way symmetrical. Setiap program yang dirancang pemerintah memerlukan dukungan publik, oleh karena itu dibutuhkan komunikasi yang saling pengertian dan memahami untuk membuat kebijakan maupun saling memberi dan menerima pelayanan publik dalam upaya membentuk pemerintahan demokratis yang efektif (Maulina, 2015).

Hal ini kemudian membuat para peneliti saat ini lebih memperhatikan manajemen hubungan online, termasuk kualitas hubungan, strategi, dan interaktivitas. Pendapat - pendapat di atas sesuai dengan teori excellent public relations yang menekankan komunikasi dua arah antara organisasi dengan publiknya. Selain itu, kekuatan audience seperti umpan balik dan aktivisme sangat terkait dengan interaktivitas dalam media untuk membangun hubungan dan melakukan komunikasi dua arah yang lebih baik. Teori difusi dalam media sosial terkait dengan penyebarluasan informasi dan teori dialogic public relations dari Kent dan Taylor (Demetrious, 2013; Nahon \& Hemsley, 2013; Rainie \& Wellman, 2012). Dengan melihat dan mempertimbangkan fakta-fakta yang ada, munculnya internet dianggap sebagai media interaktif yang memiliki efek yang signifikan pada pembangunan hubungan antara organisasi 
dan publik. Selain itu, publik tidak akan bisa meminta pertanggungjawaban pemerintah mereka apabila mereka tidak tahu apa yang dilakukan pemerintah dan tidak memiliki saluran untuk berinteraksi dengan pemerintah (Welch and Wong, 1998, 2001a).

Dengan diberlakukannya Undang-Undang Nomor 14 Tahun 2008 tentang Keterbukaan Informasi Publik (KIP) seharusnya bisa menjadi semangat baru bagi lembaga publik untuk mengungkapkan informasi kepada publik dan menjadi momentum bagi publik untuk memperoleh informasi dari lembaga publik (Open Government Indonesia tahun 2011). Mereka diharuskan untuk memberikan informasi yang transparan dan dapat dipertanggungjawabkan serta menyediakan ruang dialog bagi publik untuk menghindari kesenjangan informasi (Welch, et al., 2005).

Penting bagi praktisi hubungan masyarakat untuk mempertimbangkan faktor-faktor lain disamping norma-norma sosial dalam forum digital (seperti berbagi pesan dalam lintas platform) untuk membuat kampanye dengan mengoptimalkan untuk aliran informasi di mana format, informasi terkait, dan hyperlink tertanam dapat membantu mencapai hasil yang diharapkan(Hon, 2015; Jin \&Liu, 2010)sehingga publik dapat menilai kinerja lembaga publik dan dapat memberikan aspirasi dan masukan dalam pembuatan kebijakan oleh badan publik di Indonesia. Untuk itu perlu dilakukan evaluasi untuk memverifikasi apakah hasil penelitian dan pernyataan beberapa ahli tentang praktik e-government di beberapa negara berkembang yang menjalankan sistem demokrasi seperti di Indonesia guna memastikan pengungkapan informasi dari badan publik kepada publiknya. Berdasarkan urgensi yang disebutkan di atas, penelitian ini dilakukan berdasarkan beberapa asumsi, termasuk asumsi bahwa penegakan peraturan keterbukaan informasi publik seharusnya telah membuat semua lembaga publik di Indonesia secara transparan dan akuntabel menginformasikan kepada publik dalam praktik public relations online di bentuk tampilan website berdasarkan penggunaan fitur strategi pemeliharaan fitur pemeliharaan relasional sehingga dapat meningkatkan persepsi positif dan memenuhi harapan publik. Selain itu, evaluasi penerapan public relations online dalam kerangka kerja e-government oleh lembaga publik di Indonesia diperlukan untuk memperoleh pemahaman yang komprehensif tentang isu-isu seputar tata kelola informasi seperti keterbukaan, partisipasi, akuntabilitas dan transparansi dalam kerangka demokrasi yang dituangkan dalam peraturan hukum yang berlaku di Indonesia.

Sejauh ini belum ada penelitian yang mengevaluasi penerapan e-government sebagai bentuk aplikasi public relations online 
yang dilakukan oleh public relations badan publik melalui tampilan fitur dalam website resmi badan publik di Indonesia. Manajemen relasional menyediakan kerangka kerja yang dapat digunakan untuk mengeksplorasi makna fungsi utama public relations untuk organisasi dan masyarakat. Hal ini bukan tanpa alasan karena Public relations yang melakukan pendekatan dialogis akan berfokus pada publik dan memposisikan diri untuk menjadi lebih inklusif dalam menerima suara-suara aktivis yang akan berkembang melampaui pandangan biner dari pemangku kepentingan dan publik yang saling berhubungan (Demetrious, 2013).

Beberapa teori yang digunakan dalam penelitian ini adalah Organization Public Relationship Management Theory, Relational Maintenance Strategies Online Theory, Technology Determinism Theory, and Media richness Theory. Relationship Management dapat memberikan kerangka kerja yang dapat digunakan untuk mengeksplorasi makna fungsi utama humas bagi organisasi dan masyarakat. Hal ini juga membuat pemindahan pemikiran Grunig dari awalnya dalam bentuk empat model tradisional ke dalam pengembangan dan pemeliharaan hubungan sebagai tujuan utama dari fungsi humas (Hon \& Grunig, 1999). Manfaat positif dari aplikasi Public relations online dalam bentuk e-government harus dirasakan oleh organisasi atau masyarakat.
Humas pemerintah harus mampu membangun dan memelihara hubungan baik dengan publik. Hon dan Grunig (1999) menerapkan strategi hubungan pemeliharaan ini untuk meneliti humas yang kemudian diidentifikasi menjadi enam strategi utama dengan menambahkan access kedalam lima strategi yang telah disarankan oleh Stafford dan Canary (1991) yaitu positivism, openness, assurances, networking, and sharing of tasks.

\section{Korelasi Organization Public Relationship} Management Theory dengan studi ini didasarkan pada pendapat Cutlip, Center, dan Broom (2016) yang menyatakan bahwa humas dilihat sebagai fungsi dari manajemen untuk bisa membangun dan memelihara hubungan yang saling menguntungkan antara organisasi dan masyarakat yang dapat mempengaruhi keberhasilan atau kegagalan suatu organisasi. Oleh karena itu, peningkatan informasi dari pemerintah ke publiknya dapat membantu meningkatkan persepsi positif publik dan mempengaruhi harapan serta kepercayaan publik dengan cara mempersempit kesenjangan informasi antara publik dan pemerintah (Welch, et al., 2005). Teori public relations telah menggambarkan bagaimana media sosial telah mengubah praktik public relations dan menggambarkan komunikasi interaktif dialogis sebagai sebuah norma (Coombs, 2014; Hon, 2015; Taylor \& Kent, 2014). 
Dalam studi ini, peneliti mencoba untuk meneliti seberapa jauh hubungan antara badan publik di Indonesia dengan publik dan upaya apa yang telah dilakukan untuk membangun dan mempertahankan hubungan tersebut. Perkembangan teori ini menjadi teori strategi pemeliharaan relasional online yang kemudian menjadi unit analisis dalam mengevaluasi Public relations online dalam website resmi di beberapa instansi pemerintah di Indonesia. Strategi pemeliharaan relasional digunakan untuk menjaga hubungan organisasi dan publik. Ki (2006) mengemukakan bahwa beberapa strategi pemeliharaan relasional akan memprediksi hasil dari hubungan tersebut. Strategi pemeliharaan relasional memberikan perhatian yang relatif sedikit terhadap hasil atau kualitas hubungan, tetapi beberapa peneliti menyarankan pentingnya strategi pemeliharaan relasional dan implikasi dari strategi ini. Strategi pemeliharaan relasional kemudian di konsep ulang oleh Ki (2006) untuk diterapkan dalam situasi online. Teori strategi pemeliharaan relasional online akan digunakan sebagai unit analisis dalam mengevaluasi public relations online dalam website di beberapa instansi pemerintah di Indonesia. Peneliti ingin melihat seberapa jauh interaktivitas dibangun oleh website pemerintah berdasarkan enam strategi pemeliharaan relasional yang disampaikan oleh Grunig dan Hunt (1999). Apabila kita perhatikan, model public relations yang berpusat pada organisasi dalam komunikasi berbasis web telah menyerukan orientasi baru untuk komunikasi public relations online yang bergerak menjauh dari model simetris dua arah ke arah perspektif publik yang mengakomodasi banyak tingkat interaktivitas digital dan prinsip-prinsip dialogis tentang mutualitas, keterbukaan, dan pembangunan hubungan (Taylor \& Kent, 2014).

Dalam teori Determinasi Teknologi yang melihat budaya dibentuk oleh cara orang berkomunikasi sejalan dengan perkembangan aplikasi public relations online, dengan perkembangan teknologi komunikasi dalam praktik hubungan masyarakat, humas badan publik harus mengikuti dan mengambil keuntungan dari perkembangan jaman yang terjadi dengan menggunakan media baru seperti internet untuk melakukan kegiatan atau praktik Public relations. Dengan kata lain, public relations online tidak hanya memindahkan praktik public relations tradisional di media internet tetapi perlu inovasi untuk memanfaatkan kehadiran internet itu sendiri. Korelasi Teori Determinisme Teknologi dengan penelitian ini adalah keberadaan internet sebagai media baru harus ditangani secara bijaksana oleh lembaga-lembaga publik di Indonesia dalam menyampaikan pengungkapan informasi kepada publik. Ini mengacu pada pendapat White 
dan Raman (2000) yang mengatakan bahwa kehadiran internet harus dianggap sebagai media utama public relations dalam suatu organisasi untuk secara langsung berinteraksi dengan para pemangku kepentingan. Dengan mempertimbangkan struktur dalam suatu hubungan dapat membantu menjelaskan dan memprediksi perilaku termasuk bagaimana kelompok dan individu dapat merespons pesan atau gagasan baru (Kadushin, 2012).

Korelasi Media Richness Theory (Wood \& Smith, 2005) dengan penelitian ini adalah pengembangan internet sebagai media baru dari media tradisional yang ada sebelumnya dan peneliti akan mengevaluasi penggunaan Teknologi Informasi dan Komunikasi (TIK) untuk membangun aplikasi public relations secara online transparan dan bertanggung jawab dalam menyampaikan informasi kepada publik di era keterbukaan informasi publik.

\section{METODE PENELITIAN}

Penelitian ini menggunakan metode mixed methods dengan sequential explanatory, desain penelian menggunakan campuran dua fase. Desain ini juga dapat digunakan oleh peneliti lain jika mereka ingin memperoleh informasi berdasarkan hasil data kuantitatif dan akan ditindaklanjuti dengan penelitian kualitatif. Populasi yang diteliti pada penelitian ini adalah badan publik yang telah ditetapkan dalam
Peraturan Komisi Informasi No. 1 tahun 2010 tentang Standar Layanan Informasi Publik. Dalam penelitian ini, peneliti menggunakan proporsional stratified random sampling berdasarkan penilaian keterbukaan informasi lembaga publik pada tahun 2016 yang dilakukan

oleh Komisi Informasi Pusat Republik Indonesia yang dibagi menjadi enam kategori yang masing-masing memiliki 10 sampel dan satu kategori yang memiliki 4 sampel. Keenam kategori tersebut termasuk kategori badan publik kementerian, badan publik lembaga negara, badan publik lembaga non-struktural, badan publik pemerintah provinsi, badan publik BUMN, badan publik dari universitas negeri. Sedangkan satu kategori lainnya adalah kategori partai politik nasional.

Penelitian ini menganalisis website resmi badan publik di Indonesia menggunakan enam strategi pemeliharaan hubungan yang dibahas di atas: positive, access, openness, networking, a common task, and guarantees. Unit analisis penelitian ini adalah website badan publik di Indonesia. Paradigma yang digunakan dalam penelitian ini adalah positivisme. Penelitian ini bersifat deskriptif. Penelitian ini melakukan analisis konten kuantitatif berfokus pada fitur sistematis dan konten tertentu dari website badan publik di Indonesia. Penelitian deskriptif bertujuan untuk memberikan gambaran secara sistematis, faktual dan akurat tentang fakta- 
fakta dan sifat populasi atau objek tertentu.

Untuk mendapatkan data yang lebih mendalam tentang aktivitas public relations online, peneliti melakukan wawancara mendalam kepada petugas humas atau orang yang ditunjuk untuk itu. Dalam penelitian ini, data kualitatif digunakan untuk memperjelas data kuantitatif. Data kualitatif diperoleh melalui wawancara mendalam dengan para responden. Metode penelitian kualitatif digunakan untuk mendapatkan gambaran pemahaman humas badan publik terhadap transparansi dan akuntabilitas dalam aplikasi public relations online yang mereka tuangkan dalam fitur dan konten sistematis dari website resmi mereka.

Teknik pengumpulan data pada penelitian ini menggunakan eksplorasi sekuensial. Pengumpulan data melibatkan studi dokumenter. Teknik pengambilan sampel menggunakan proportional stratified random sampling berdasarkan peringkat transparansi informasi yang diberikan oleh Komisi Informasi Pusat Republik Indonesia yang terdiri dari tujuh kategori. Enam kategori adalah kategori umum dan satu kategori spesifik. Setiap kategori umum terdiri dari 10 sampel, sedangkan kategori khusus memiliki 4 sampel. Keenam kategori umum meliputi: badan publik kementerian, badan publik non-kementerian, badan publik non-struktural, badan publik pemerintah provinsi, badan publik BUMN, dan badan publik perguruan tinggi negeri. Kategori spesifik adalah partai politik nasional.

Pengukuran skor ini dilakukan dengan Confirmatory Factor Analysis (CFA). Hasil pengukuran ini diubah dalam bentuk persentase untuk memperkirakan tingkat kecenderungan penggunaan fitur yang mewakili indikator penelitian, dan juga untuk memahami faktor dominan dalam setiap indikator. Penelitian ini menggunakan analisis faktor untuk menganalisis interdependensi lintas variabel. Faktor skor yang penulis gunakan adalah:

$\mathrm{S}-\mathrm{Fa}=\mathrm{c}^{\prime} \mathrm{R}^{-1} \mathrm{Zj}$

Keterangan:

$\mathrm{S}-\mathrm{Fa}$ : Score Factor

c': Eigen Vector

$\mathrm{R}^{-1}$ : Matrix Inverse

$\mathrm{Zj}$ : Observed Score

Semakin tinggi skor yang diperoleh maka semakin transparan dan dapat dipertanggungjawabkan informasi yang diperoleh publik dari aktivitas public relations online. Semakin rendah skornya, semakin tidak transparan dan akuntabel adalah penyampaian informasi kepada publik. Teknik analisis data adalah analisis kuantitatif. Ini digunakan untuk mengolah data menggunakan tabel distribusi frekuensi. Di sini, tabel distribusi frekuensi membantu penulis untuk memeriksa distribusi frekuensi dan persentase diseminasi (Kriyantono, 2012; Bungin, 2014). 


\section{HASIL DAN PEMBAHASAN}

Evaluasi fungsi dan fitur pada website resmi badan publik berdasarkan indikator analisis strategi pemeliharaan relasional dengan indikator evaluasi yang pertama yaitu positivity, peneliti menekankan 5 fitur tertanam dalam website sebagai indikator yaitu fitur sitemap, fitur game atau multimedia, fitur pencarian informasi, fitur menu utama, dan fitur RSS. Hasil evaluasi menunjukkan mayoritas atau 28 sampel website $(43,75 \%)$ badan publik di Indonesia memiliki kecenderungan penggunaan fitur positivity dalam kategori menuju positivity (MP), 19 sampel website $(29,69 \%)$ memiliki kecenderungan penggunaan fitur positivity dalam kategori cukup positivity (CP), 13 sampel website (20,31\%) memiliki kecenderungan penggunaan fitur positivity dalam kategori positivity (P), 3 sampel website (4,69\%) memiliki kecenderungan penggunaan fitur positivity dalam kategori kurang positivity (KP), dan 1 sampel website (1,56\%) memiliki kecenderungan penggunaan fitur positivity dalam kategori tidak positivity (TP).

Evaluasi fungsi dan fitur pada website resmi badan publik berdasarkan indikator analisis strategi pemeliharaan relasional dengan indikator evaluasi yang kedua yaitu openness. Peneliti menekankan tiga fitur tertanam dalam website sebagai indikator yaitu fitur berita organisasi, fitur berita atau informasi organisasi melalui email personal publik, dan fitur kolom komentar bagi publik. Hasil evaluasi menunjukkan mayoritas atau 42 sampel website $(65,63 \%)$ badan publik di Indonesia memiliki kecenderungan penggunaan fitur openness dalam kategori cukup openness (CO), 14 sampel website (12,50\%) memiliki kecenderungan penggunaan fitur openness dalam kategori openness $(\mathrm{O}), 8$ sampel website $(21,88 \%)$ memiliki kecenderungan penggunaan fitur openness dalam kategori tidak openness (TO), dengan kata lain tidak ada badan publik yang termasuk dalam kategori peringkat menuju openness (MO) dan kurang openness (KO).

Evaluasi fungsi dan fitur pada website resmi badan publik berdasarkan indikator analisis strategi pemeliharaan relasional dengan indikator evaluasi yang ketiga yaitu accessibility, peneliti menekankan tiga fitur tertanam dalam website sebagai indikator yaitu fitur alamat email, fitur informasi kontak, dan fitur meminta pertanyaan atau komentar dari publik. Hasil evaluasi menunjukkan mayoritas atau 43 sampel website $(67,19 \%)$ badan publik di Indonesia memiliki kecenderungan penggunaan fitur accessibility dalam kategori cukup accessibility (CAc), 19 sampel website (29,69\%) memiliki kecenderungan penggunaan fitur accessibility dalam kategori accessibility (Ac), 2 sampel website $(3,13 \%)$ memiliki 
kecenderungan penggunaan fitur accessibility dalam kategori tidak accessibility (TAc), dengan kata lain tidak ada badan publik yang termasuk dalam kategori peringkat menuju accessibility (MAc) dan kurang accessibility (KAc).

Evaluasi fungsi dan fitur pada website resmi badan publik berdasarkan indikator analisis strategi pemeliharaan relasional dengan indikator evaluasi yang keempat yaitu assurances, peneliti menekankan lima fitur tertanam dalam website sebagai indikator yaitu fitur yang memungkinkan publik untuk mengupload artikel dan grafis, fitur daftar hadir atau tamu, fitur message board, dan fitur login. Hasil evaluasi menunjukkan mayoritas atau 29 sampel website $(45,31 \%)$ badan publik di Indonesia memiliki kecenderungan penggunaan fitur assurances dalam kategori kurang assurances (KAs), 17 sampel website (29,69\%) memiliki kecenderungan penggunaan fitur assurances dalam kategori tidak assurances (TAs), 15 sampel website $(23,44 \%)$ memiliki kecenderungan penggunaan fitur assurances dalam kategori cukup assurances (CAs), dan 3 sampel website (4,69\%) memiliki kecenderungan penggunaan fitur assurances dalam kategori menuju assurances (MAs). Dengan kata lain tidak ada badan publik yang termasuk dalam kategori peringkat assurances (As).

Evaluasi fungsi dan fitur pada website resmi badan publik berdasarkan indikator analisis strategi pemeliharaan relasional dengan indikator evaluasi yang kelima yaitu networking, peneliti menekankan dua fitur tertanam dalam website sebagai indikator yaitu fitur kontak dengan kumpulan aktivis tertentu seperti aktivis lingkungan, kemasyarakatan maupun lembaga swadaya masyarakat lainnya, dan fitur forum dialog. Hasil evaluasi menunjukkan mayoritas atau 48 sampel website (75\%) badan publik di Indonesia memiliki kecenderungan penggunaan fitur networking dalam kategori tidak networking (TN), 11 sampel website $(17,19 \%)$ memiliki kecenderungan penggunaan fitur networking dalam kategori kurang networking $(\mathrm{KN})$, dan 5 sampel website $(7,81 \%)$ memiliki kecenderungan penggunaan fitur networking dalam kategori networking (N). Dengan kata lain tidak ada badan publik yang termasuk dalam kategori peringkat menuju networking (MN) dan cukup networking (CN).

Evaluasi fungsi dan fitur pada website resmi badan publik berdasarkan indikator analisis strategi pemeliharaan relasional dengan indikator evaluasi yang keenam yaitu sharing task, peneliti menekankan empat fitur tertanam dalam website sebagai indikator yaitu fitur mengundang publik untuk berpartisipasi dalam sebuah komunitas, fitur yang mengundang publikuntuk berpartisipasi dalam kampanye atau event tertentu, fitur meminta pendapat publik 
dari kebijakan yang dibuat, dan fitur pengaduan publik. Hasil evaluasi menunjukkan mayoritas atau 50 sampel website $(78,13 \%)$ badan publik di Indonesia memiliki kecenderungan penggunaan fitur sharing task dalam kategori tidak sharing task (TST), 8 sampel website $(12,50 \%)$ memiliki kecenderungan penggunaan fitur sharing task dalam kategori cukup sharing task (CST), dan 6 sampel website $(9,38 \%)$ memiliki kecenderungan penggunaan fitur sharing task dalam kategori kurang sharing task (KST). Dengan kata lain tidak ada badan publik yang termasuk dalam kategori peringkat sharing task (ST) dan menuju sharing task (MST). Dari hasil analisis kuantitatif karakteristik public relations online badan publik di Indonesia menggunakan indikator strategi pemeliharaan relasional diatas, peneliti berargumentasi bahwa regulasi keterbukaan informasi publik telah membuat website badan publik di Indonesia mengimplementasikan strategi pemeliharaan relationship dalam praktik public relations online selama ini meskipun masih belum bisa dikatakan ideal. Dari beberapa definisi organization-public relationship (OPR) yang ada, lebih menekankan pada relasi yang menjadi fokus inti dari aktivitas public relations (Kriyantono, 2014).

Implementasi strategi public relations online harus diterapkan dalam website yang dijalankan oleh badan publik di Indonesia sebagai negara demokrasi dalam kerangka e-government. Untuk melihat penerapan Undang-Undang Keterbukaan Informasi Publik (UU KIP) dan memastikan hak publik untuk memperoleh informasi yang transparan dan dapat dipertanggungjawabkan dapat dilihat dengan menggunakan enam analisis strategi pemeliharaan relasional dan diukur menggunakan Confirmatory Factor Analysis (CFA). Oleh karena itu, dalam penelitian ini peneliti mencoba untuk mengevaluasi sejauh mana pembinaan relasi antara lembaga publik di Indonesia dengan publik dan upaya apa yang telah dilakukan untuk membangun dan mempertahankan hubungan tersebut. Teori strategi pemeliharaan relasional online menjadi unit analisis dalam mengevaluasi public relations online di situs web agensi publik di Indonesia.

Hasil evaluasi fungsi dan fitur pada website resmi badan publik dengan indikator analisis strategi pemeliharaan relasional menggunakan metode pengukuran Confirmatory Factor Analysis (CFA) kemudian dikonversi menjadi persentase angka rata-rata dengan indikator evaluasi positivity, openness, accessibility, assurances, networking, and sharing task. Berdasarkan 6 kategori analisis, tinjauan umum strategi pemeliharaan relasional website badan publik di Indonesia dapat kita lihat pada tabel 1.

Persentase Strategi Pemeliharaan 
Tabel 1 Persentase Strategi Pemeliharaan Relasional dari Lembaga Publik Penerima Penghargaan Keterbukaan Informasi Publik pada tahun 2016

\begin{tabular}{|c|c|c|c|c|}
\hline NO & Website Badan Publik & CFA & Analisis CFA $(\%)$ & Peringkat \\
\hline 1 & www.kpk.go.id & 1.832049 & 96.65279 & MR \\
\hline 2 & www.jatengprov.go.id & 1.759857 & 96.0784 & MR \\
\hline 3 & www.sumselprov.go.id & 1.290238 & 90.15159 & MR \\
\hline 4 & www.bappenas.go.id & 1.275888 & 89.90024 & MR \\
\hline 5 & www.komnasham.go.id & 1.265115 & 89.7085 & MR \\
\hline 6 & www.partaigerindra.or.id & 1.259498 & 89.60748 & MR \\
\hline 7 & www.ppatk.go.id & 1.196897 & 88.43266 & MR \\
\hline 8 & www.bawaslu.go.id & 1.150933 & 87.512 & MR \\
\hline 9 & www.lipi.go.id & 1.014974 & 84.4941 & MR \\
\hline 10 & www.lapan.go.id & 0.9786 & 83.61113 & MR \\
\hline 11 & www.ugm.ac.id & 0.9786 & 83.61113 & MR \\
\hline 12 & www.ub.ac.id & 0.931223 & 82.4131 & MR \\
\hline 13 & www.bppt.go.id & 0.756101 & 77.52056 & $\mathrm{CR}$ \\
\hline 14 & www.kemenperin.go.id & 0.703337 & 75.90772 & $\mathrm{CR}$ \\
\hline 15 & www.jasatirta2.co.id & 0.64637 & 74.09803 & $\mathrm{CR}$ \\
\hline 16 & www.lkpp.go.id & 0.631146 & 73.60273 & $\mathrm{CR}$ \\
\hline 17 & www.kemenpan.go.id & 0.411436 & 65.96237 & $\mathrm{CR}$ \\
\hline 18 & www.kpu.go.id & 0.408 & 65.83632 & $\mathrm{CR}$ \\
\hline 19 & www.mahkamahkonstitusi.go.id & 0.40605 & 65.76471 & $\mathrm{CR}$ \\
\hline 20 & www.um.ac.id & 0.36624 & 64.29069 & $\mathrm{CR}$ \\
\hline 21 & www.acehprov.go.id & 0.261128 & 60.30033 & $\mathrm{CR}$ \\
\hline 22 & www.ntbprov.go.id & 0.193908 & 57.68759 & $\mathrm{KR}$ \\
\hline 23 & www.anri.go.id & 0.188937 & 57.49288 & KR \\
\hline 24 & www.jatimprov.go.id & 0.130141 & 55.17727 & KR \\
\hline 25 & www.pks.or.id & 0.130141 & 55.17727 & KR \\
\hline 26 & www.depkes.go.id & 0.0436 & 51.73882 & $\mathrm{KR}$ \\
\hline 27 & www.ui.ac.id & 0.021575 & 50.86067 & $\mathrm{KR}$ \\
\hline 28 & www.batan.go.id & 0.011985 & 50.47814 & KR \\
\hline 29 & www.kominfo.go.id & -0.00916 & 49.63443 & $\mathrm{KR}$ \\
\hline 30 & www.bi.go.id & -0.03539 & 48.58838 & $\mathrm{KR}$ \\
\hline 31 & www.bpws.go.id & -0.07177 & 47.13942 & $\mathrm{KR}$ \\
\hline 32 & www.unib.ac.id & -0.07597 & 46.97218 & $\mathrm{KR}$ \\
\hline 33 & www.pu.go.id & -0.20092 & 42.03789 & $\mathrm{KR}$ \\
\hline 34 & www.kaltimprov.go.id & -0.20092 & 42.03789 & $\mathrm{KR}$ \\
\hline 35 & www.pelindo.co.id & -0.20092 & 42.03789 & KR \\
\hline 36 & www.unpad.ac.id & -0.2483 & 40.19506 & $\mathrm{KR}$ \\
\hline 37 & www.kai.id & -0.27992 & 38.97712 & TR \\
\hline 38 & www.jakarta.go.id & -0.32588 & 37.22578 & TR \\
\hline 39 & www.kalbarprov.go.id & -0.32588 & 37.22578 & TR \\
\hline 40 & www.kemenkeu.go.id & -0.37326 & 35.44788 & TR \\
\hline 41 & www.dephub.go.id & -0.37326 & 35.44788 & $\mathrm{TR}$ \\
\hline 42 & www.perhutani.co.id & -0.37326 & 35.44788 & TR \\
\hline 43 & www.pln.co.id & -0.37326 & 35.44788 & $\mathrm{TR}$ \\
\hline 44 & www.itb.ac.id & -0.37326 & 35.44788 & TR \\
\hline
\end{tabular}




\begin{tabular}{|c|c|c|c|c|}
\hline 45 & www.pertanian.go.id & -0.37864 & 35.24766 & $\mathrm{TR}$ \\
\hline 46 & www.unlam.ac.id & -0.49821 & 30.91674 & TR \\
\hline 47 & www.ipb.ac.id & -0.49821 & 30.91674 & TR \\
\hline 48 & www.sumbarprov.go.id & -0.54979 & 29.12309 & TR \\
\hline 49 & www.taspen.co.id & -0.55097 & 29.08254 & TR \\
\hline 50 & www.kppu.go.id & -0.55097 & 29.08254 & TR \\
\hline 51 & www.btn.co.id & -0.63893 & 26.14344 & TR \\
\hline 52 & www.komisiyudisial.go.id & -0.64313 & 26.00688 & TR \\
\hline 53 & www.bpbatam.go.id & -0.64313 & 26.00688 & TR \\
\hline 54 & www.ombudsman.go.id & -0.67054 & 25.12556 & TR \\
\hline 55 & www.kompolnas.go.id & -0.67054 & 25.12556 & TR \\
\hline 56 & www.bantenprov.go.id & -0.67054 & 25.12556 & $\mathrm{TR}$ \\
\hline 57 & www.hanura.or.id & -0.67593 & 24.95425 & $\mathrm{TR}$ \\
\hline 58 & www.biofarma.co.id & -0.71651 & 23.68389 & TR \\
\hline 59 & www.unand.ac.id & -0.86143 & 19.45008 & TR \\
\hline 60 & www.seteneg.go.id & -0.89304 & 18.59169 & TR \\
\hline 61 & www.len.co.id & -0.93622 & 17.45808 & TR \\
\hline 62 & www.inti.co.id & -1.06117 & 14.43059 & TR \\
\hline 63 & www.bpkp.go.id & -2.0224 & 2.156749 & TR \\
\hline 64 & www.pan.or.id & -2.27231 & 1.153387 & TR \\
\hline
\end{tabular}

Sumber: Hasil Olahan Data Penelitian, 2016

Relasional dari Lembaga Publik Penerima Penghargaan Keterbukaan Informasi Publik pada tahun 2016.

Tabel 1 menyajikan data hasil pengukuran implementasi strategi public relations online badan publik di Indonesia yaitu untuk badan publik dengan persentase kecenderungan untuk menggunakan fitur strategi pemeliharaan relasional tertinggi yang dimiliki oleh website Komisi Pemberantasan Korupsi $96.65 \%$ dan terbawah dimiliki oleh website Partai Amanat Nasional (PAN) 15\%. Hasil evaluasi implementasi public relations online dalam menjalankan strategi pemeliharaan relasional secara umum dapat dilihat pada gambar 1 .
Histogram Penggunaan Fitur Strategi Pemeliharaan Relasional Oleh Badan Publik Penerima Penghargaan Keterbukaan Informasi Publik pada tahun 2016.

Deskripsi hasil evaluasi dapat dilihat dari gambar 1, kita bisa melihat mayoritas atau 28 website sampel $(43,75 \%)$ badan publik di Indonesia cenderung menggunakan fitur pemeliharaan relasional dalam kategori tidak relasional (TR), 15 website sampel $(23,44 \%)$ memiliki Kecenderungan untuk menggunakan fitur pemeliharaan hubungan dalam kategori kurang relasional (KR), 13 sampel website (20,31\%) memiliki kecenderungan untuk menggunakan fitur pemeliharaan hubungan 
Histogram of pr2

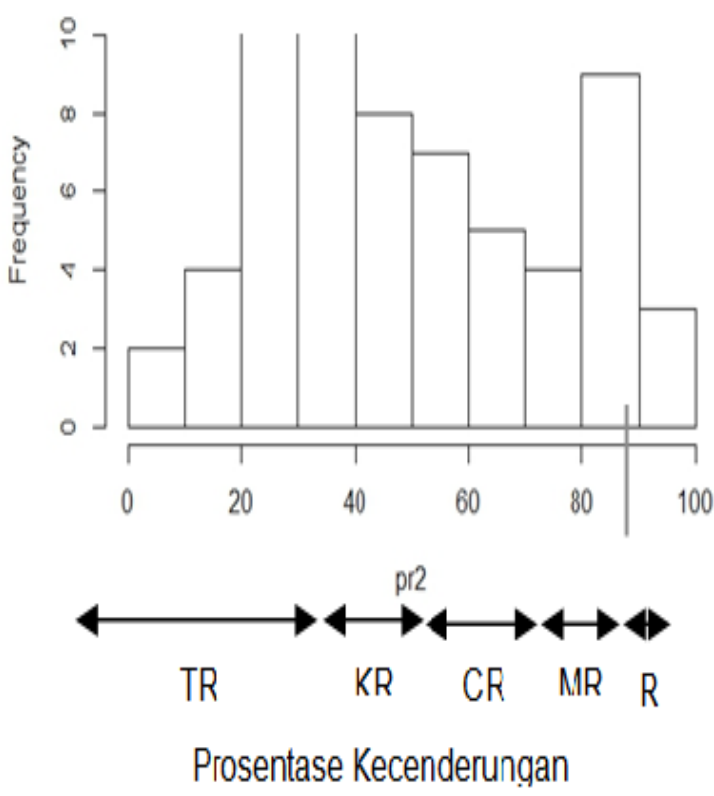

Gambar 1 Histogram Penggunaan Fitur Strategi Pemeliharaan Relasional Oleh Badan Publik Penerima Penghargaan Keterbukaan Informasi Publik pada tahun 2016

dalam kategori Cukup Relasional (CR), dan 9 sampel website (14,06\%) memiliki kecenderungan untuk menggunakan fitur pemeliharaan hubungan dalam kategori hubungan yang menuju relasional (MR). Dari hasil analisis data ini, kita dapat melihat bahwa hingga penelitian ini dilakukan, tidak ada badan publik yang ideal atau termasuk kategori relasional (R). Ini berarti bahwa strategi pemeliharaan relasional online di sebagian besar badan publik di Indonesia memiliki kecenderungan untuk menggunakan fitur pemeliharaan hubungan yang masih rendah dan perlu ditingkatkan.

Melihat hasil analisis di atas menunjukkan bahwa mayoritas atau 28 sampel situs web $(43,75 \%)$ dari lembaga publik di Indonesia memiliki kecenderungan untuk menggunakan fitur pemeliharaan hubungan dalam kategori tidak relasional (TR), padahal tugas public relations sebagai komunikator adalah untuk membantu organisasi membina hubungan jangka panjang dengan publik strategis mereka (Grunig, Grunig dan Dozier, 2002). Penelitian ini menggunakan enam strategi pemeliharaan relasional (Grunig \& Huang, 1999) sebagai variabel penelitian yang dapat digunakan sebagai referensi bagi praktisi public relations dan humas badan publik untuk membangun praktik public relations online di website resmi mereka dalam upaya untuk mengimplementasikan UU No. 14/ 2008 tentang Keterbukaan Informasi Publik (KIP) khususnya dalam menjalankan strategi pemeliharaan relasional dengan masyarakat.

Hasil analisis menunjukkan bahwa public relations atau humas badan publik di Indonesia memiliki kecenderungan belum menggunakan fitur strategi pemeliharaan relasional yang ideal untuk menyebarkan pesan organisasi melalui diskusi yang lebih persuasif dan belum mengadopsi model komunikasi simetris dua arah yang menekankan pentingnya keterlibatan dan membangun hubungan jangka panjang dengan publik sehingga hak publik untuk mengakses informasi yang transparan dan 
dapat dipertanggungjawabkan belum dipenuhi secara ideal karena isu-isu tata kelola informasi seperti keterbukaan, partisipasi, akuntabilitas dan transparansi dalam kerangka demokrasi di Indonesia belum terakomodir dalam fitur yang digunakan dalam meningkatkan tingkat kepercayaan dan legitimasi lembaga-lembaga publik di Indonesia. Komisi Informasi yang bertanggungjawab melakukan pemantauan dan evaluasi (Monev) tentang implementasi UU No.14 / 2008 tentang Keterbukaan Informasi Publik (Pasal 26 ayat 2 huruf c UU KIP) harus menjadikan strategi pemeliharaan relasional ini sebagai salah satu unsur dari penilaian yang harus dipenuhi oleh badan publik dalam mengimplementasikan UU KIP.

Dari hasil wawancara dengan informan, diperoleh data bahwa pemeliharaan relasional dianggap penting dan selalu dilakukan upaya agar relasional ini tetap dijaga sehingga publik selalu mengunjungi website badan publik. Ada fenomena yang menarik dari hasil wawancara yaitu pemeliharaan relasional yang dilakukan oleh humas badan publik lebih menekankan pada pemeliharaan relasional dalam fitur media sosial di luar website resmi badan publik dari pada menanamkan fitur pemeliharaan relasional dalam website resmi mereka. Pembangunan fitur berupa link media sosial menjadi saluran berita untuk dapat berbagi berita serta memberikan komentar dan tanggapan atau mengajukan pertanyaan daripada membuat fitur email resmi untuk publik yang ingin mencari informasi. Padahal, pemanfaatan fitur ini terkait dengan komunikasi internal atau antar-lembaga, konektivitas dengan website lainnya, memastikan informasi pembaruan, dan mengakomodasi tanggapan atas keluhan yang diajukan sesuai dengan hukum dan peraturan yang berlaku.

Terkait dengan pemeliharaan relasional dengan publik, peneliti bertanya tentang fitur yang telah tertanam di website badan publik untuk mempertahankan relasional dengan publik. Hasilnya adalah sebagian besar informan mengatakan bahwa perbaikan masih dilakukan dari fitur yang ada. Fitur-fitur ini termasuk fitur media sosial, audio visual, telepon dan email, terkait dengan lembaga pemerintah, formulir online, mesin telusur, menjaga lotalitas pelanggan, dan mudah diakses dengan gagdet oleh publik. Dari wawancara di atas dapat disimpulkan bahwa humas badan publik memiliki pemahaman tentang pemeliharaan relasional lebih difokuskan pada aktivitas di media sosial dibandingkan dengan fitur-fitur lain yang ada pada beberapa indikator strategi pemeliharaan hubungan. Terkait dengan penyebarluasan informasi, perlu digarisbawahi perlunya pemahaman tentang perbedaan inti antara media tradisional dan difusi informasi media baru dalam aliran informasi jaringan 
ke jaringan digital yang cepat dan efek media "supersizing" yang membantu membentuk makna dan pesan yang disampaikan (Hon, 2015; Nahon \& Hemsley, 2013). Dalam konsep kerangka tindakan pribadi dan kolektif yang digunakan oleh kelompok aktivis dan gerakan sosial untuk menggalang dukungan seputar isu tertentu dari individu dan kelompok dalam media online memberikan peluang untuk penelitian public relations tentang pembangunan koalisi melalui pembangunan hubungan relasi secara pribadi maupun pengaruh media online (Bennett \& Segerberg, 2012). Proposisi yang dapat diambil adalah platform media sosial masih merupakan pilihan utama humas badan publik di Indonesia dalam upaya pemeliharaan relasional dengan publik daripada membangun website resmi dengan fitur strategi pemeliharaan hubungan yang ideal di dalam website resmi untuk membangun jangka panjang hubungan dengan publik strategisnya.

Sebagai negara yang menerapkan UndangUndang Keterbukaan Informasi Publik sebagaimana diatur dalam Undang-undang Nomor 14/2008, menjadi kewajiban setiap badan publik di Indonesia untuk memberikan warga hak atas layanan informasi yang transparan dan dapat dipertanggungjawabkan sebagai bentuk layanan publik (UndangUndang Nomor 25/2009 tentang Layanan Publik) yang diimplementasikan dalam fitur pemeliharaan relasional di website resmi mereka sebagai bagian dari strategi public relations online badan publik di Indonesia daripada lebih menekankan pada fungsi manajemen media sosial (Keputusan Menteri Kepegawaian Nasional Nomor 83/2012 tentang pedoman pemanfaatan media sosial lembaga pemerintah) dengan menanamkan fitur strategi pemeliharaan relasional di website untuk membantu organisasi membangun hubungan jangka panjang dengan publik strategis mereka. Smith and Ferguson (2010) menunjukkan bahwa aktivitas komunikasi dalam media sosial itu sendiri adalah bentuk public relations, karena pada dasarnya publik secara aktif telah menciptakan kampanye dan taktik komunikasi strategis sebagai cara untuk mencapai tujuan tertentu. oleh karena itu, mereka telah mempraktikkan fungsi public relations.

Selain mengukur tingkat persentase kecenderungan terhadap strategi pemeliharaan relasional, peneliti juga mengukur faktor dominan dari strategi pemeliharaan relasional dalam praktik public relations online yang dilakukan oleh badan publik di Indonesia menggunakan Confirmatory Factor Analysis (CFA) yang dapat kita lihat pada tabel 2 . Pengukuran Faktor Dominan dalam Analisis Strategi Pemeliharaan Relasional

Dari tabel 2 kita dapat melihat bahwa fitur aksesibilitas merupakan faktor dominan dalam 
Tabel 2 Pengukuran Faktor Dominan dalam Analisis Strategi Pemeliharaan Relasional

Total Variance Explained

\begin{tabular}{cccc}
\hline No & $\begin{array}{c}\text { Component } \\
\text { Total }\end{array}$ & $\begin{array}{c}\mathrm{I} \mathrm{n} \mathrm{i} \mathrm{t} \text { i a } \\
\text { Eigenvalues } \\
\text { \% of Variance }\end{array}$ & Cumulative \\
\hline 1 & 1.925 & 32.090 & 32.090 \\
2 & 1.390 & 23.172 & 55.262 \\
3 & 0.941 & 15.685 & 70.947 \\
4 & 0.832 & 13.867 & 84.813 \\
5 & 0.510 & 8.502 & 93.315 \\
6 & 0.401 & 6.685 & 100.000 \\
\hline
\end{tabular}

Extraction Method: Principal Component Analysis. Component Matrix

\begin{tabular}{lc}
\hline & Component 1 \\
\hline Positivity & 0.387 \\
Openness & 0.631 \\
Access & $0.747^{*}$ \\
Assurances & 0.585 \\
Networking & 0.319 \\
Sharing Task & 0.613 \\
\hline
\end{tabular}

Extraction Method: Principal Component Analysis.

a. Componenet Ectracted.

*. Item Dominant

implementasi public relations online badan publik di Indonesia. Ini menunjukkan bahwa aksesibilitas merupakan prioritas dalam public relations online badan publik di Indonesia untuk membangun hubungan jangka panjang dengan publik. Badan publik harus lebih memperhatikan fitur pemeliharaan relasional lainnya dalam membangun dan memelihara hubungan dengan publik.

Namun, peneliti menyadari bahwa penelitian ini memiliki kelemahan karena penelitian ini hanya berfokus pada badan publik penerima Keterbukaan Informasi Publik pada tahun 2016 dengan asumsi bahwa badan publik mewakili semua badan publik yang memiliki website terbaik di Indonesia. Jadi masalah generalisasi muncul sebagai keterbatasan penelitian ini karena objek penelitian tidak mewakili dan mencerminkan semua website badan publik di Indonesia. Selain itu, penelitian ini hanya berfokus pada pengukuran fitur strategi pemeliharaan relasional. Padahal sebenarnya masih banyak fitur lain yang belum digunakan sebagai indikator dalam penelitian ini. Penelitian ini bukan penelitian longitudinal yang dapat mengukur data sebelum dan sesudah evaluasi sehingga hasilnya tidak dapat digunakan sebagai pembanding. Selain itu, penelitian ini tidak dapat diterapkan terus menerus karena faktor pengembangan teknologi sehingga perlu dipertimbangkan untuk mengukur dengan menggunakan indikator lain sesuai dengan perkembangan teknologi.

\section{SIMPULAN}

Berdasarkan analisis strategi pemeliharaan relasional, humas badan publik lebih cenderung menggunakan platform media sosial untuk pemeliharaan relasional dengan publik daripada mengoperasionalkan fitur strategi pemeliharaan relasional di website resmi mereka. Hal ini disebabkan oleh adanya kesalahpahaman cara pandang (miskonsepsi) humas badan publik di Indonesia dalam mendefinisikan aktivitas public 
relations online identik dengan pemanfaatan media sosial dalam kegiatan kehumasan.

Secara garis besar dapat ditarik benang merah bahwa humas badan publik salah memahami definisi Public relations online dan kurangnya bimbingan teknis dari implementasi Undang-Undang Nomor 14/2008 memberikan dampak yang kurang menguntungkan dalam mencapai tujuan akhir dari peraturan keterbukaan informasi publik. Rupanya peraturan Keterbukaan Informasi Publik tidak cukup untuk memberikan jaminan transparansi dan akuntabilitas informasi. Penelitimenemukan bahwa penggunaan platform media sosial dianggap lebih aman oleh publikasi hubungan masyarakat di Indonesia karena alasan hacker, menjaga citra komentar publik negatif, dan budaya penggunaan bahasa Indonesia yang oleh publik yang terkadang kurang sopan dan tidak layak dikonsumsi oleh publik. Diperlukan kerangka acuan dan pengalaman di bidang kehumasan dalam meningkatkan pengelolaan website yang informatif dan dialogis dan mampu menjalin hubungan baik dengan publik untuk mewujudkan transparansi dan akuntabilitas informasi.

Peneliti berpendapat bahwa pendekatan ilmiah dari perspektif ilmu komunikasi lebih komprehensif daripada metode evaluasi dari Komisi Informasi. Hal ini disebabkan karena indikator dalam penelitian ini telah diujikan di negara-negara maju seperti di Eropa dan Korea Selatan oleh beberapa peneliti yang bereputasi. Peneliti telah melakukan pengujian dan penyesuaian dengan budaya demokrasi di Indonesia sebelum diaplikasikan dalam penelitian ini. Hasil penelitian ini dapat menjadi bahan rujukan dan bimbingan teknis bagi praktisi humas badan publik dalam menjalankan strategi public relations online dalam mengelola website. Bagi pembuat kebijakan, hasil penelitian ini dapat dijadikan acuan atau referensi untuk menentukan indikator penilaian keterbukaan informasi publik yang lebih valid, reliable, dan komprehensif. Dari sisi akademis, hasil penelitian ini dapat menambah studi untuk humas terutama public relations online, manajemen website dan manajemen konten spesifik dalam website.

Kementerian Komunikasi dan Informatika, dalam hal ini Komisi Informasi sebagai lembaga yang bertanggung jawab atas pelaksanaan Undang-Undang Nomor 14/2008, harus memberikan bimbingan teknis yang dapat menjadi kerangka acuan dan pemahaman bagi humas badan publik. Pedoman teknis dimaksudkanuntukpengembanganwebsiteyang informatif dan dapat dipertanggungjawabkan.

Peneliti merekomendasikan kepada Kementerian Komunikasi dan Informasi untuk menggunakan indikator dalam penelitian ini yaitu fitur strategi pemeliharaan relasional 
dalam program evaluasi berikutnya. Humas badan publik harus terus berimprovisasi dalam membangun website, terutama pada fitur-fitur strategi pemeliharaan relasional. Selain itu, Kementerian Komunikasi dan Informatika harus menyelenggarakan program sosialisasi dan edukasi tentang pentingnya public relations online untuk humas badan publik dan praktisi humas di Indonesia secara komprehensif agar tercipta pemahaman yang sama dari masingmasing praktisi humas di setiap badan publik tentang pentingnya humas pemerintah untuk dapat membina hubungan relasional yang baik dengan masyarakat dengan memanfaatkan website yang mereka miliki. Tantangan yang harus dijawab oleh humas pemerintah saat ini adalah mewujudkan website yang menghasilkan lebih banyak informasi dan lebih memungkinkan untuk berbagi informasi dengan masyarakat, dengan memanfaatkan fitur-fitur yang mendukung transparansi dan akuntabilitas. Tujuannya adalah untuk meningkatkan legitimasi dan kepercayaan masyarakat terhadap kinerja badan publik.

\section{DAFTAR PUSTAKA}

Bennett, W. \& Segerberg, A. (2012). The logic of connective action: Digital media and the personalization of contentious politics. Information, Communication, \& Society, 15(05), 739-768.

Bungin, B. (2014). Metodologi penelitian kuantitatif: Komunikasi, ekonomi, dan kebijakan publik serta ilmu sosial lainnya. Jakarta: Prenadamedia.

Boczkowski, P. J. \& Mitchelstein, E. (2012). How users take advantage of different forms of interactivity on online news sites: Clicking, e-mailing, and commenting. Human Communication Research, 38(1), $1 \mathrm{e} 22$.

Brown, B., Sikes, J., \& Willmott, P. (2013). Bullish on digital: McKinsey global survey results. McKinsey Quarterly, 12, 1-8.

Castells, M. (2015). Networks of outrage and hope: Social movements in the internet age. John Wiley \& Sons.

Caywood, C. L. (1997). The handbook of strategic public relations and integrated communications. McGraw-Hill.

Coombs, W. T. (2014). State of crisis communication: Evidence and the bleeding edge. Research Journal of the Institute for Public Relations, 1(1), 1-12.

Cutlip, S. M., Center, A. H., \& Broom, G. M. (2006). Effective public relations. New Jersey: Pearson Education Inc.

Demetrious, K. (2013). Public relations, activism, and social change: Speaking up. Routledge research in public relations. Florence, KY: Routledge.

Duhé, S. (2015). An overview of new media research in public relations journals from 1981 to 2014. Public Relations Review, 41(2), 153-169.

Grunig, L. A., Grunig, J. E., Dozier, D. M. (2002). Excellence in public relations and communication management: A study of communication management in tree countries. Mahwah, NJ: Lawrence Erlbaum Associates.

Grunig, J. E. \& Huang, Y. H. (1999). Od kazalcev organizacijske uspesnosti $h$ 
kazalcem odnosov: Povodi, strategije in resultati odnosov z javnostmi (From organizational effectiveness to relationship indicators: Antecedents of relationships, public relations strategies, and relationship outcomes). Teoriji in Praksa. 36, 644-667. Holzschlag, M. E. (2001). Freedom in structure. Web Techniques, 6(7), 26-30.

Hon, C. L. \& Grunig, J. E. (1999). Guidelines for measuring relationships in public relations. The Institute for Public relations, University of Florida. Diakses tanggal 16 Mei 2019. http://www.instituteforpr.org/ research_single/guidelines_measuring_ relationships (accessed November 6, 2006).

Hon, L. (2015). Digital social advocacy in the Justice for Trayvon Campaign. Journal of Public Relations Research, 27(4), 299-321.

Ishak, A. (2011). Revitalisasi Public Relations Organisasi Pemerintah dalam Upaya Pencapaian Penguatan Masyarakat. Aswad Ishak dan Setia Budi HH (ed). Public Relations dan Corporate Social Responsibility. Jakarta: ASPIKOM, Buku Literas, BPC Humas Yogyakarta.

Jin, Y. \& Liu, B. F. (2010). The blogmediated crisis communication model: Recommendations for responding to influential external blogs. Journal of Public Relations Research, 22(4), 429-455.

Kadushin, C. (2012). Understanding social networks: Theories, concepts, and findings. New York, NY: Oxford University Press

Kelleher, T. (2007). Public relations online lasting concept for changing media. London: Sage Publications.

Kent, M. L., \& Saffer, A. J. (2014). A Delphi study of the future of new technology research in public relations. Public relations Review, 40(3), 568-576.

Ki, E.J. (2006). Linkages among relationship maintenance strategies, relationship quality outcomes, attitude and behavioral intentions. Unpublished doctoral dissertation. University of Florida, Gainesville, FL.

Kriyantono, R. (2012). Teknik praktis riset komunikasi: Disertai contoh praktis riset public relations, komunikasi organisasi, media massa dan pemasaran. Jakarta: Prenada media.

Kriyantono, R. (2014). Teori public relations perspektif barat dan lokal: Aplikasi penelitian \& praktik. Jakarta: Prenada Media.

Maulina, N. (2015). Dalam upaya meningkatkan komunikasi dua arah antara humas pemerintah dengan publik eksternal. Meta Communication Jurnal Ilmu Komunikasi. ISSN 2356-4490.

McQuail, D. (2010). McQuail's mass communication theory. Los Angeles, London, Singapore: Sage.

Nahon, K. \& Hemsley, J. (2013). Going viral. Cambridge, UK: Polity Press.

Peraturan Komisi Informasi No. 1 tahun 2010 tentang Standar Layanan Informasi Publik

Peraturan Menteri Pendayagunaan Aparatur Negara Dan Reformasi Birokrasi Republik Indonesia Nomor 83 Tahun 2012 tentang Pedoman Pemanfaatan Media Sosial Instansi Pemerintah.

Permenpan Nomor 30 Tahun 2011 tentang Pedoman Umum Tata Kelola Kehumasan di Lingkungan Instansi Pemerintah.

Petrovici, M. A. (2014). E-Public relations: Impact and Efficiency. $A$ case study. Procedia-Social and Behavioral Sciences, 141, 79-84.

Pina, V., L. Torres \& Acerete, B. (2007a). 'Are ICTs promoting government accountability? a comparative analysis 
of e-governance developments in 19 oecd countries'. Critical Perspectives on Accounting. 18(5), 583-602.

Pratchett, L. (1999). 'New technologies and the modernization of local government: An analysis of biases and constraints'. Public Administration. 77(4), 731-50.

Rainie, L., \& Wellman, B. (2012). Networked: The new social operating system. Cambridge, MA: MIT Press.

Sala. (2003). E-democracy in practice 2003. Swedish experiences of a new political tool. Stockholm: Swedish Association of Local Authorities and Swedish Federation of County Councils and Regions.

Stafford, L. \& Canary, D.J. (1991). "Maintenance strategies and romantic relationship type, gender, and relational characteristics". Journal of Social and Personal Relationships. (8)217-42.

Sunarto. (2011). Public relations untuk Pelayanan Publik. 2011. Wacana, Volume $\mathrm{X}$, Nomor 2.

Smith, M. F. \& Ferguson, D. P. (2010). Activism. In Heath, R. (Ed.) Handbook of public relations, pp. 291-300. Thousand Oaks, CA: Sage.

Taylor, M. \& Kent, M. L. (2014). Dialogic engagement: Clarifying foundational concepts. Journal of Public Relations Research, 26(5), 384-398.

Torres , L., Pina, V., and Acerete, B. (2006). E-governance developments in EU cities. Reshaping government's relationship with citizens' governance. Online Information Review. 12(9), 277 - 302.

Undang-Undang Nomor 14/2008 Tentang Keterbukaan Informasi Publik
Undang-undang Nomor 25/2009 Tentang Layanan Publik.

Voorveld, H. A., Van Noort, G., \& Duijn, M. (2013). Building brands with interactivity: The role of prior brand usage in the relation between perceived website interactivity and brand responses. Journal of Brand Management, 20(7), 608-622.

Welch, C. H. \& Moon, M.J. (2005). 'Linking citizen satisfaction with e-government and trust in government'. Journal of Public Administration Research and Theory. 15 (3), 371-91.

Welch, Eric, \& Wilson, W. (1998). Public administration in a global context: Bridging the gaps of theory and practice between western and non-western nations. Public Administration Review. 58,40-49.

Welch, Eric, \& Wilson, W. (2001). Global information technology pressure and government accountability: The mediating effect of the domestic context on website openness. Journal of Public Administration Theory and Research. 11, 509-538.

White \& Raman. (2000). "The world wide web as a public relations medium: The use of research, planning, and evaluation in website development." Public Relations Review. 25(4), 405-419.

Wood, A. F. \& Smith, J. M. (2005). Online communication: linking technology, identity and culture. New Jersey: Lawrence Erlbaum Associates, Inc.

Yang, A. \& Taylor, M. (2015). Looking over, looking out, and moving forward: Positioning public relations in theorizing organizational network ecologies. Communication Theory, 25(1), 91-115. 